ДАРКО ЛЕИТНЕР-СТОЈАНОВ

UDC: $94(=114.2 / .3)(093)$

СТЕФАН ПАНОВСКИ

929-055.1(=114.2/.3)(093)

Институт за национална историја

Скопје, Македонија

\title{
„САГАТА ЗА ОСТРОГОТА“ И CODEX VINDOBONENSIS HIST. GR. 73
}

\begin{abstract}
Ancmpaкm. - Статијата се занимава со прашањето за историчноста на готскиот крал Острогота, кој досега во современата историографија беше сметан за фиктивен или митолошки карактер. Врз основа на анализата на најновиот изворен материјал и неговата споредба со Гетика од Јорданес и други доцноантички пишани извори, статијата дебатира со последните историографски трудови за неговото постоење односно непостоење, и заклучува дека сепак Острогота бил реална историска личност активна кон средината на III век. Целта на статијата е да се вклучи во тековните истражувања поттикнати од откривањето на шестте нови фрагменти од делото Скитика на Дексип во Австриската национална библиотека. Во таа насока, два од листовите $\left(f .194^{\mathrm{r}}\right.$ и $\left.f .194^{\mathrm{v}}\right)$ од Codex Vindobonensis Hist. gr. 73 се преведени на македонски јазик и се појдовна точка за статијата, а заедно со останатите фрагменти и за следни истражувања поврзани со историјата на Готите и нивните односи со Римското царство во III век.
\end{abstract}

1. Во време кога се поретко се откриваат нови пишани извори за историјата на антиката и средниот век, појавата на само еден ракопис може да донесе големи промени во толкувањето на минатото, или, пак, во најмала рака да предизвика преиспитување на старите дискусии. Токму тоа се случува во изминатите пет години во академските кругови кои се занимаваат со историјата на Готите или пак со кризата на Римското царство во III век.

За што станува збор? Истражувајќи ги старите збирки во Австриската национална библиотека во Виена, во 2008 година една работна група од Австриската академија на науките стигнала до Codex Vindobonensis Hist. gr. 73 од X век, досега познат по Constitutiones Apostolorum, збирка црковно-правни текстови од IV век. ${ }^{1}$ Ракописот е всушност палимпсест и во подолните слоеви содржи извадоци од други извори (Херодијан, Василиките, Хрониката на Евзебиј од Цезареја, Животот на Св. Ѓорѓи, и За церемониите), меѓу кои засега најголемо внимание во научната јавност привлекуваат

\footnotetext{
${ }^{1}$ Grusková, 2012: 76.
} 
фрагментите од „Скитика“ на Дексип од Атина (втора половина на III век), препишани најверојатно во првата половина на XI век. ${ }^{2}$ Палимпсестот е проучуван врз база на дигитални ултравиолетови слики, при што првиот од низата фрагменти е објавен во 2010 година. ${ }^{3}$ Тоа што упатувало на делото Скитика од Дексип се јазикот и стилот на текстот, како и споменувањето на готскиот водач Книва. ${ }^{4}$ Притоа, засега не е можно да се утврди дали листовите се дел од директна копија на Скитика, или копија на друго (непознато) дело, или пак на тематски поделена збирка на историски изводи со долги цитати. Листовите биле предмет на анализа со најнови методи на спектрално скенирање, со цел да се подготви критичко издание со детална студија на историскиот текст и на самиот ракопис. ${ }^{5}$ Главни истражувачи на овој палимпсест се Јана Грускова и Гунтер Мартин, ангажирани од Австриската академија на науките.

Од 11 листа, 6 фрагменти (ff. 192v, 193r, 194r, 194v, 195r, $195 \mathrm{v})$, напишани на класицизирачки грчки, опишуваат барбарски напади во балканските провинции на Римското царство во периодот $c$. 250-270 година. Тие веќе успеаја да отворат поширока дебата и продукција на статии кои полека се претвораат во база на нови толкувања за периодот на големите инвазии. Се разбира, како и секое античко дело зачувано само во подоцнежни фрагменти, толкувањето на новиот материјал подразбира значителни ограничувања и недоречености. Тешко е да се знае дали текстот е во целост верен препис или пак е контаминиран или можеби парафразиран, со што особено се отежнува деталната јазична и историска анализа. Дополнително, некои зборови не може целосно и јасно да се прочитаат, дури и по употребата на најсовремени лабораториски средства. Но, и покрај тоа, содржината на фрагментите е уникатна и нуди нови податоци што досега не беа познати. Новите фрагменти нудат можности за дополнителни истражувања на хронологијата, историската географија, просопографијата, политичката историја, итн. Повторно се разгледуваат правците и обемот на готските инвазии, хронологијата на нападите, динамиката на односите меѓу готските водачи, односите меѓу провинциското население и римската централна власт, и примената на воените тактики. ${ }^{6}$

${ }^{2}$ Ibid., 69-82.

${ }^{3}$ Grusková, 2010.

${ }^{4}$ Grusková, 2012: 76.

${ }^{5}$ Ibid., 77.

${ }^{6}$ E.g. Mallan \& Davenport, 2015: 203-226, кои со прилично уверливи анализи го потврдуваат авторството на атинецот Публиј Херениј Дексип и истовремено покажуваат дека тој не е еден од водачите на Хелените собрани кај Термопилите туку дека спомнатиот е најверојатно бојотархот Куртиј Дексип од Хајронеја; понатаму, го идентификуваат провинцискиот управник на Ахаја и водач кај Термопилите како Маријан наместо предложениот Маркијан; ја поместуваат хронологијата на првата голема готска инвазија од 253/4 година (како што се веруваше досега) во 
2. Готите дошле во понепосреден и подолготраен контакт со Римското царство приближно во 30-те години на III век, во моментот кога од Померанија (каде биле дел од археолошката култура Вилбарк) се доселиле и стабилизирале на северните брегови на Црното море. Од материјална гледна точка, таму учествувале и биле водечки елемент во културата Чернијаков, која доминира во тие региони во III и IV век. ${ }^{7}$ Во локалните борби за моќ и влијание, Готите успеале да се наметнат над голем дел од населението, ${ }^{8}$ а потоа и да го мобилизираат за големи ограбувачки походи на римска територија, на југо-запад кон балканските провинции и на југо-исток кон малоазиските провинции. Во нивно друштво ги среќаваме Гепидите, Карпите, Тајфалите, Вандалите, Херулите, Бастарните, Сарматите и други племиња. Иако во почетокот на големите походи доста важна улога имале Карпите, а некаде кон крајот и Херулите, сепак водечка сила во центарот на овие инвазии биле Готите, па затоа и нивното име доминира во современата историографија. Античките автори пак, најчесто ги запишувале под групното и архаизирачко име Скити. Со оглед на тоа што во прво време добивале годишна сума пари од царството, во 240-те години нивните напади биле со ограничен карактер и главно се концентрирале на Мезија. Но, кога во 248 година императорот Филип престанал да ги исплаќа, започнала војна во текот на која се одиграле неколку големи битки во Мезија и Тракија, и Готите покажале дека умеат да преземаат и посложени воени операции а не само мали погранични упади. ${ }^{9}$ Биле опсадени или освоени, меѓу другите, Маркијанопол, Никопол крај Истар, Филипопол, а во 251 година, императорот Декиј и неговиот син Херениј Етруск ги загубиле животите во битката кај Абритус. Новиот император, Требонијан Гал, повторно почнал да плаќа годишни суми на Готите. ${ }^{10}$ По извесно затишје, готските инвазии го добиле својот најголем опфат и интензитет во две големи навлегувања: првиот бран $c$. 262 (односно c. 253/4 според старата хронологија) и вториот бран

c. 262 година. Од големите историски настани, повторно се анализираат опсадата на Филипопол од Готите на Книва во летото 250 година и одбраната кај Термопилите во 262 година (според новото датирање), cf. Grusková \& Martin, 2014: 29-43; Grusková \& Martin, 2015: 35-53; Grusková \& Martin, 2017a: 267-281. За разни други аспекти, види ја растечката литература, Martin \& Grusková, 2014a: 101-120; Martin \& Grusková, 2014b: 728-754; Piso, 2015: 199-215; Grusková \& Martin, 2017b: 40-46; Hostein, 2017: 37-64.

${ }^{7}$ Cf. Wolfram, 1990: 55.

${ }^{8}$ Всушност, воспоставувањето на оваа нова констелација воопшто не била ниту лесна, ниту мирољубива. Археолошките извори упатуваат на уништување и напуштање на цели населби, односно на потиснување на некои од групите кои претходно живееле во тие региони. Истовремено, преку археолошките извори може да се забележи и зближување и мешање на културите. $C f$. Schukin, Kazanski \& Sharov, 2006: 37 .

${ }^{9}$ Christol, 1997: 121; Wolfram, 1990: 58.

${ }^{10}$ Christol, 1997: 127. 
c. $267 / 8$ година. ${ }^{11}$ Истовремено, готски поморски експедиции напаѓале и на источниот брег на Црното море и во Мала Азија. ${ }^{12}$ Покрај руралните средини, нивна цел биле и градовите како Тесалоника, Атина, Аргос и други. ${ }^{13}$ Падот на Атина во т.н. "херулска“" инвазија (c. 268) зазема препознатливо, па дури и романтизирано место во историографијата, затоа што токму споменатиот П. Херениј Дексип, угледен и богат Атињанец, организирал еден вид локална милиција со цел да ги попречува барбарските акции во областа и да го ослободи градот, а подоцна своето искуство од војната го запишал во делото Скитика. ${ }^{14}$

3. Едно од прашањата што одново се наметнуваат во оваа римско-готска приказна, во контекст на новите фрагменти од „Скитика“, е она за постоењето на кралот Острогота, кој досега беше познат само од „Гетика“ на Јорданес (VI век). Таму го среќаваме во четири прилики: во генеалогијата на Амалите, при објаснувањето на потеклото на етнонимот Остроготи, при готските напади на царството во средината на III век, и во војната меѓу Готите и Гепидите северно од Дунав. ${ }^{15}$ Прикажувајќ́ ја лозата на готските кралеви од династијата Амали, Јорданес го позиционира Острогота на шестото место, како внук на Амал и син на Хисарнис. Во текот на 17 генерации, во една поедноставена варијанта, вака оди списокот на Јорданес: Гапт - Хумал - Аугис - Амал - Хисарнис - Острогота - Хунуил - Атал - Ахиулф - Вултулф - Валараванс Винитариј - Вандалариј - Теодимир - Теодорих - Амаласунта Матасунта. ${ }^{16}$ Така, од личностите кои се релевантни за оваа дискусија, Амал ја претставува четвртата генерација, Острогота шестата, Херманарик (брат на Вултулф) десетата, а Теодорих петнаесеттата. Според Јорданес, кој сака да ги прикаже почетоците и крајот на оваа славна кралска фамилија, овие податоци се веродостојни и

11 За поретката варијанта: 257 и 268 година, cf. Mussot-Goulard, 1999: 26.

12 Goltz, 2008: 215.

${ }^{13}$ Kulikowski, 2006: 19; Wolfram, 1990: 60.

14 За животот и дејноста на Дексип, како и за социо-културниот живот и интелектуалните традиции во неговото време, $c f$. Millar, 1969: 12-29. За освојувањето на Атина, Frantz, 1988: 1-15. За поголемите сочувани фрагменти од „Скитика“ пред откривањето на виенскиот палимпсест релевантни за готските инвазии на Балканот, v. Dexippos, BNJ 100, F 25 (опсадата на Маркијанопол), F 26 (писмото од имп. Декиј до граѓаните на Филипопол), F 27 (опсадата на Филипопол), F 28 (говорот на Дексип пред Атињаните по падот на градот). $C f$. Davenport \& Mallan, 2013: 59.

${ }^{15}$ Iord., Getica $14.79,14.82,16.90-92$ и 17.98-100.

${ }^{16}$ Iord., Getica, 14.79. Во списокот во неколку случаи се наведени и странични гранки, односно браќата на некои од кралевите, како на пример Одулф (како брат на Ахиулф); Ансила, Едиулф и Херманарик (како браќа на Вултулф); Валамир и Видимир (како браќа на Теодимер), и Аталарик (како брат на Матасунта). Дополнително е прикажана лозата од страната на кралот Херманарик, која многу подоцна преку Еутарик и неговиот брак со Амаласунта се спојува во Матасунта, Iord., Getica, 14.81. 
доаѓаат од усните традиции на самите Готи, ${ }^{17}$ иако не треба да се заборави дека уште пред него Касиодор, чија историја на Готите ја ползувал, имал составено слична генеалогија. ${ }^{18}$ Понатаму, според Јорданес, додека живееле покрај Црното Море во Скитија оној дел од Готите кој ги населувал источните делови и бил под власта на Острогота биле наречени Остроготи - при што не е сигурен дали нивното име доаѓ од името на водачот или пак од географската позиција (источни Готи). ${ }^{19}$ Во третата епизода каде што се спомнува неговото име, Острогота конечно прераснува во историска личност и зема учество во историските собитија. Во времето на императорот Филип Арабјанинот (244-249), според Јорданес Готите веќе биле господари на огромни пространства во Скитија и имале потчинето бројни народи (Вандали, Маркомани, Квади). Истовремено, биле и федерати на Римското царство, и за тоа добивале годишни суми. ${ }^{20}$ Инвазиите започнуваат во моментот кога спомнатиот император престанал да ги плаќа. Тогаш, токму Ocтрогота го преминал Дунав со својата војска и ги опустошил Мезија и Тракија. Во пресрет му бил испратен сенаторот Декиј, но тој бидејќи немал моќ да се спротивстави на Готите отпуштил дел од римските војници како казна за наводна небрежност и потоа се вратил кај императорот. Војниците, пак, разочарани од таквата неправедна постапка, преминале кај кралот Острогота. ${ }^{21}$ Тој, слушајќи за нивното лошо искуство, собрал огромна војска од Готи и околни племиња, 22 ја ставил под водство на истакнатите војсководачи Аргаит и Гунтерик, и ја упатил во нов напад на царството. Повторно пустошејќи ја Мезија, Готите го опседнале Маркијанопол, а кога, по подолго време, граѓаните платиле откуп, тие си заминале и се вратиле зад Дунав со голем плен. ${ }^{23}$ Според современите историчари, доколку се прифатат во било каков формат, овие

${ }^{17}$ Iord., Getica, 14.78.

18 Во писмо до римскиот сенат од $c .533$ година, редејќи ги заслугите на Касиодор, кралот Аталарик (526-534) спомнува дека тој составил генеалогија на Амалите со 17 генерации, Cassiod., Variae, 9.25.4. Теоретски, како брат и сестра, Аталарик и Матасунта се во истата, последна, генерација, но интересно е тоа што во својата верзија од генеалогијата, Јорданес го изоставува кралот Аталарик и оди директно на Матасунта, која не била владетел и која тешко дека би можела да фигурира во првата верзија на генеалогијата кај Касиодор. Ова, пак, го отвара прашањето дали генеалогиите кај Касиодор и Јорданес целосно се совпаѓаат, односно, сугерира дека е можно Јорданес (пишувајќи две децении подоцна и во друг контекст) да извршил одредени интервенции во генеалогијата.

${ }^{19}$ Iord., Getica, 14.82, иако во истиот пасус во случајот на Визиготите ја следи само географската логика (западни Готи).

${ }^{20}$ Ibid., 16.89 .

${ }^{21}$ Ibid., 16.90 .

22 Покрај Готите се спомнуваат и Вандали (т.е. Хаздинги), Тајфали, Карпи, и Бастарни (т.е. Пеукини), Iord., Getica, 16.91.

${ }^{23} \mathrm{Ibid} ., 16.92$ и 17.94. Но, според Дексип опсадата завршила со пораз на Готите (Dexippos, BNJ 100, F 25). 
два готски напади би требало да се датираат во 248 и 249 година. $^{24}$ На крајот, во четвртата приказна за Острогота Јорданес вели дека успесите на Готите предизвикале завист кај Гепидите, сроден народ во соседството, кои почнале да се подготвуваат за војна. ${ }^{25}$ Всушност, дознаваме дека во меѓувреме власта на Гепидите се зголемувала над соседните народи, и во одреден момент нивниот крал Фастида решил дека е време да го сврти вниманието кон Готите. Испратил пратеници до Острогота, кој според Јорданес во тоа време бил крал и на Визиготите и на Остроготите, барајќи од него да му отстапи земја за населување или пак да се соочи со војна. Откако Острогота го одбил барањето, двете војски се судриле во близина на населбата Галтис. По жестоката целодневна битка, вечерта поразените Гепиди се повлекле, а Готите останале да живеат среќни на својата територија се додека владеел Острогота. ${ }^{26}$ По неговата смрт, се чини дека власта ја зел Книва. Вака, накратко, би ги сумирале приказите за Острогота кај Јорданес. Во продолжение тој опишува готски инвазии водени од Книва во 250251 , склучување договор со Готите во време на императорот Требонијан Гал, а подоцна и нови готски инвазии кон Мала Азија и Тракија водени од Респа, Ведук и Туруар во 261/2 година. ${ }^{27}$

4. Во современата историографија главно е прифатено гледиштето дека кралот Острогота е фиктивен лик, односно митологизиран херој. Името Острогота/Острогута ${ }^{28}$ ни беше познато единствено преку „Гетика“ на Јорданес од VI век, автор кој има репутација за второстепен извор и чии податоци секогаш се земаат со голема резерва. Последново важи особено за неговата генеалогија на готските кралеви од амалската династија, за која со право се смета дека е поврзана со онаа составена од Касиодор заради потребите на готскиот кралски двор во Равена. ${ }^{29}$ Мислењата за фиктивноста на Острогота се темелат главно на два аргументи - дека неговото име е анахронизам или политичка манипулација во изворите.

Според повеќето истражувачи се чини нелогично да постои антропоним Острогота пред да постои етноним Остроготи, ${ }^{30}$ додека пак поделбата на Готите на Визиготи и Остроготи се случила

${ }^{24}$ Cf. Devillers, 1995: 149, n. 150 за доаѓањето на сенаторот Декиј во Мезија есента 248 година, во врска со побунетите војници, настан што ако го поврземе со приказната кај Јорданес се совпаѓa со кусиот период меѓу двете готски навлегувања. За заминувањето на Декиј од Мезија во летото 249 , со што границата била оставена небранета пред вториот готски напад, cf. Wolfram, 1990: 58.

${ }^{25}$ Iord., Getica, 17.94.

${ }^{26}$ Ibid., 17.97-100.

${ }^{27}$ Ibid., 18.101-103, 19.106, и 20.107-109.

28 За разните варијанти и транскрипции на името Острогота v. Grusková \& Martin, 2014: 35.

${ }^{29}$ Cf. Geary, 2004: 81-82; Heather, 1989: 107-109.

${ }^{30} \mathrm{Cf}$. Wofram, 1990: 36. 
многу подоцна - според едни, најрано кон крајот на III век (кога за првпат се спомнуваат Тервингите) или поверојатно кон крајот на IV век (кога, во засебни прилики, за првпат се спомнуваат Греутунги, Вези/Визиготи, и Остроготи), ${ }^{31}$ а според други во V век и тоа во сосема поинаков контекст и со поинакво значење. ${ }^{32}$ Со оглед на тоа што Острогота се среќава приближно 40 години пред поделбата на Готите и 140 години пред етнонимот Остроготи, а згора на тоа се споменува единствено кај Јорданес во VI век, во современата историографија немаше дилеми дека тој не постоел и станува збор за анахронизам во историјата на Јорданес. Острогота остана зафрлена белешка во историографијата, со општа согласност дека станува збор за митски владетел. ${ }^{33}$ Сепак, има и ретки случаи на негирање на оваа аргументација. На пример, за М. Б. Шчукин во историска перспектива постоењето на антропоним пред етноним не е нешто невидено, и тој го користи Острогота во своите анализи. ${ }^{34}$

Кон ова треба да се додаде и толкувањето дека вметнувањето на Острогота во генеалогијата на готските владетели што го среќаваме кај Јорданес е всушност политичка манипулација направена на равенскиот двор од страна на сенаторот Касиодор, чија дванаесеттомна историја на Готите била основа за делото на Јорданес и кој, како што беше спомнато, веќе имал составено генеалогија на Амалите. ${ }^{35}$ Идејата е дека со таа генеалогија Теодорих сакал да обезбеди политички легитимитет на својата династија и да ја користи во внатрешната и надворешната политика. Со личност наречена според името на народот што го владее, а по кој впрочем е крстена една од неговите керки (Острогото), ${ }^{36}$ Теодорих

31 Тервинги во 291 г. во XII Panegyrici Latini XI (III) 17, 1; Вези во с. 388-391 во Notitia Dignitatum or. V 20 и 61, како и VI 20 и 61; Греутунги c. 392 г. во Amm. Marc. XXXI 3.5; Остроготи во септември 392 г. во Claud., In Eutrop. II, 158.

${ }^{32} C f$. Kulikowski, 2006: 111: „In fact, the division between Visigoths and Ostrogoths is a product of fifth-century politics within the Roman and Hunnic empires, and the names are retrojection from the sixth-century text of Jordanes: they bear no demonstrable relationship to fourth-century divisions. The Gothic groups that emerged in the fourth century, after Adrianople, and in the fifth century, after the collapse of the Hunnic empire, were of thoroughly mixed origin, with connections to several different Gothic polities of the fourth century".

${ }^{33}$ Меѓу другите, cf. Christol, 1997: 121 (“souverain mythique”); Heather, 1989: 106 (смета дека Острогото, керката на Теодорих, е крстена по митски предок). Според Burns, 1982: 11, некои од готските водачи спомнати од Јорданес се епонимни, притоа мислејќк најверојатно на Острогота.

${ }^{34}$ Schukin, Kazanski \& Sharov, 2006: 25-26, 53, кои се согласни дека можеби нешто не е во ред со хронологијата на она што го нарекуваат “сагата за Острогота“, но сепак воопшто не го оспоруваат историското постоење на овој крал.

${ }^{35}$ Supra, $n .18$.

${ }^{36}$ Има неколку референци за распространетоста на името Острогота/Острогото во VI век, и тоа не само кај Готите: Острогота - гепидски принц син на кралот Елемунд (Procop., Bell. Goth., IV.27), Острогото - ќерка на Теодорих Велики (Iord., 
сакал да покаже дека тој народ има „прататко“, а тој е негов директен потомок. Истовремено, во истата геналогија го среќаваме и кралот Амал, кој би бил „прататко“ на династијата, и за кој подеднакво се смета дека е измислена личност односно митски владетел, еден вид на врска меѓу боговите (Ansis-Aesir) и луѓето. ${ }^{37}$ Во таа насока, и О. Девиље, во голема мерка следејќи го Х. Волфрам, се сложува дека генеалогијата на Амалите кај Јорданес е фабрикувана и дека Острогота е измислена личност, со цел, во комбинација со подеднакво измислениот крал Амал, да се оправда власта на Амалите кај Остроготите. Тој смета дека дури кралот Херманарих во втората половина на 4 век е првиот веродостоен историски лик од генеалогијата затоа што се спомнува и кај друг автор. ${ }^{38}$ М. Куликовски исто така се сомнева во генеалогиите на Јорданес, иако неговиот фокус е повеќе на Балтите и нивната корелација со Амалите. ${ }^{39}$

5. Во новите виенски фрагменти од Дексип во две прилики се зборува за Острогота (листовите $194^{\mathrm{r}}$ и $194^{\mathrm{v}}$ ), како дел од еден непрекинат расказ. И двете сцени се однесуваат на собитијата во 250/1 година (со исклучок на првите редови кои опишуваат подоцнежни настани во Хелада), непосредно по освојувањето на Филипопол (летото 250 г. $)^{40}$ од страна на Книва и пред смртта на императорот Декиј (јуни 251 г.).

„... порака, се вознемириле од моменталната состојба и стравувале за себе (?). ${ }^{41}$ Во тие околности било решено секој од нив, колку што може да се укрепи со сопствени и сојузнички сили, и да ги варди свочте граници. Птолемај Атињанецуот - назначен од императорот за заповедник на Тесалиите - го запоседнал со гарнизони граничниот појас меѓ Македонија и Тесалија ито е природно одвоен со теснини и непристапен терен. Кај Портите

Get., 58; Anon. Val. 63), Аустригуса - ќерка на гепидскиот крал Елемунд и сестра на Острогота, подоцна сопруга на лангобардскиот крал Вахо (можно е нејзиното име да е варијанта на Острогото, аналогно на Теодихуса од Теодигота). Cf. Kleine Pauli RE 18.2, 1687-88.

${ }^{37} C f$. Wolfram, 2006: 45: „From the Ansic tradition, from the descent from Gaut / Gapt, Amal, and Ostrogotha - heroes and half-gods who 'were no mere mortals' - emerges the justification for including the Amali among the nobility of late antiquity“.

${ }^{38}$ Devillers, 1995: 145, n. 136.

${ }^{39}$ Можеби за да го избегнат непријатниот момент, Kulikowski, 2006 : 161, како и Davenport \& Mallan, 2013: 59, воопшто не го спомнуваат Острогота, иако ги користат другите ликови од приказната на Јорданес (Книва, Аргаит, Гунтерик).

40 Детали од освојувањето на Филипопол од војската на Книва исто така се опишани во новите фрагменти (f. $195^{\mathrm{r}}$ и $\left.195^{\mathrm{v}}\right)$ : Готите изведуваат лажно повлекување, а потоа по добивањето податоци за слабите точки на зидините следи и ноќна инфилтрација и борба. Од хронолошка гледна точка, за падот на градот во летото 250 година, $c f$. Wolfram, 1990: 59; за смртта на Декиј во јуни 251 година, $c f$. Devillers, 1995: 151, n. 171.

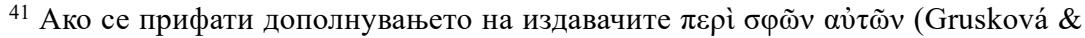
Martin, 2014: 34). 
пак пристигнале атинската и бојотската војска, и одбрани мажи од Лакедајмон; ова им изгледало како добро место да се утврдат за да го попречат nатот, а и барбарите не би можеле со леснотија да навлезат во Хелада под Портите. Вака стоеле работите кај нив".

„Кога Oстрогута - водачот на Скитите - дознал дека Филипопол бил освоен, но и дека Скитите со најголеми пофалби зборуваат за Книва па и го воспеваат во песни, ито е прастар обичај кај нив кога среќата им е наклонета и победуваат во војна, а пак него го сметаат ********u го обвинуваат за малодушност и за неуспех во воените потфати, не можел да ја поднесе ваквата состојба без да се оправда пред сите Скити со голем подвиг; набрзина собрал војска од приближно 50.000 и тргнал со намера да го нападне Декиј“. ${ }^{42}$

„Декиј бил вознемирен поради злосторството на помошните одреди и падот на Филипопол. Кога се собрала војската - приближно 80.000 на број - намислил, ако е во можност, повторно да се впушти в бој зашто и покрај загубата на помошните одреди бил во поволна положба; а и за да ги ослободи заробените Тракијчи и да го спречи нивното преминување на другата страна. Тогаш ископал ров кај Амис, месност во Бероина, и со војската се сместил во утврдувањето и внимавал кога непријателот ќе премине. Кога бил известен за приближувањето на војската на Острогота, проценил дека треба да ги охрабри војниците кога ке се укаже пригодна прилика; па кога се собрале на собирот ито го свикал, вака говорел: 'Ах мажи, камо среќ да се добри четите и поданиците, и да го избегнат понижувањето од непријателите. Сепак, како што е редот кај смртниците, човековите собитија носат секакви несреќ; но, ако некој меѓу вас се обесхрабрил, разумните луѓ треба да ги прифатат случувањата и да не ја губат одлучноста, ниту пак да се вознемират и да станат малодушни поради поразот на тоа поле и поради заробувањето на Тракијитее. Зашто и за обете несреки има објаснување - едната попрво се должи на предавството на извидниците, а не на наша слабост; градот пак во Тракија не го освоија со храброст туку со измама, откако се воздржаа од отворен напад. И немокни ... \{a не з храбри ..." ". 43

Овие реченици го враќаат Острогота во живот токму во моментот кога, според Јорданес, ја очекуваме неговата смрт. ${ }^{44}$ Новиот

${ }^{42}$ Codex Vindobonensis Hist. gr. 73, f.194r .

${ }^{43}$ Codex Vindobonensis Hist. gr. 73, f.194 $11.29-30$ et $194^{\mathrm{v}}$.

${ }^{44}$ Иако, мора да признаеме дека смртта на Острогота кај Јорданес хронолошки изгледа малку нелогична: од една страна тврди дека веднаш по смртта на Острогота, Книва ја поделил војската на два дела и започнал поход за кој со сигурност знаеме дека е во 250 година (Iord., Getica, 18.101.); значи го „умира“ Острогота во 250 г., а од друга страна, само еден ред претходно, раскажувајќ за војната 
приказ истовремено го охрабрува понатамошното иследување, но и предизвикува нов очај. Од една страна, имаме втор извор кој што го потврдува постоењето на една ретко посведочена историска личност, во голема мерка го потврдува и расказот на Јорданес за походот на Книва во Мезија и Тракија во 250 година и во извесна мера ги потврдува и воените капацитети на Острогота (доколку воопшто може да ги сметаме за прецизни), а се совпаѓа и со некои појави што ни се познати за т.н. барбарски општества, како на пример, ривалството меѓу одредени водачи и кралеви кое може да биде важен мотив за воена акција и подвиг, како и усните традиции кај барбарите кои ги опеваат успесите на своите водачи уште во текот на животот и со тоа им ги зголемуваат угледот и легитимитетот во и надвор од групата. Значи, наместо последователност во власта, во случајов би имале работа со напоредна власт што се практикува во сојузнички но истовремено и ривалски односи. Во тој правец, се отвараат неколку прашања: дали Острогота живеел и владеел и по 250 г., дали готските инвазии во 250-251 година се здружен напор на (барем) двајца водачи, дали Острогота учествувал во клучната битка кај Абритус, зошто Јорданес би го исклучил Острогота од расказот толку рано? Но пред да се стигне до нив, мора да се одговори на едно друго, поважно и основно, прашање.

6. Во новата ситуација, во која имаме спомнување на Острогота во втор извор, веднаш се отвори прашањето: дали конечно се покажа дека една од фиктивните личности кај Јорданес е всушност вистински историски крал на Готите? Прашањето беше накратко наговестено од самите откривачи на фрагментите, кои сѐ уште се презафатени со основна работа на исчитување и преведување на најдените фрагменти и немаат време целосно да се посветат на сите можни поединечни импликации што произлегуваат од ракописот. Иако, во овој случај, нивниот првичен став е прилично јасно изразен: Острогота не е подоцнежна измислица. ${ }^{45}$ Всушност, првите анализи на новоотворениот проблем со Острогота дојдоа од Х. Волфрам, чии толкувања не само за Острогота туку и за Готите воопшто, беа водечки од 1970-те па речиси до денес. Во самиот наслов на својата најскорешна статија тој го дава и својот заклучок - произлегува дека на еден митски Амал му било залепено име од еден подоцнежен историски готски водач, т.е дека Острогота е

меѓу Гепидите и Готите која се случила веднаш по последниот поход на Острогота на Балканот во 249 година, вели дека како победници Готите продолжиле да живеат во среќа и мир во својата татковина се додека Острогота бил со нив за да ги води (Iord., Getica, 17.100). Во таа смисла, би се имплицирало дека Острогота бил жив и владеел барем уште неколку години. Од наратолошки аспект ситуацијата секако е парадоксална.

${ }^{45}$ Martin \& Grusková, 2014b: 740-741. 
смешан и погрешно вметнат во една фабрикувана генеалогија. ${ }^{46}$ Во одбрана на својата ревидирана, но сепак во голема мера дамнешна и општо прифатена теза, Волфрам се потпира на неколку главни аргументи.

Прво, со оглед на тоа што за Касиодор уште во тоа време е речено дека од готските приказни за потеклото направил римска историја, ${ }^{47}$ Волфрам смета дека таквите приказни за потекло не содржат материјал со кој може да се градат историски факти, туку само митови. ${ }^{48}$ Второ, бидејќи е јасно дека почетните делови на Гетика имаат митолошки карактер, а останатите (и покрај разните грешки и нејаснотии) имаат историски карактер, произлегува дека во тоа дело Острогота го зазема местото меѓу двете концепции, онаму каде митолошкото го среќава историското, и дека поради тоа е тешко податлив за спознавање. ${ }^{49}$ Трето, според Волфрам, податокот дека генеалогијата има 17 нивоа соодветствува со разни други примери од антиката и раниот среден век и претставува еден вид општо место - Ромул како 17-ти крал по Ајнеја, Ротари како 17-ти крал на Лангобардите. Четврто, постои современ извор (панегирик) од 291 година кој зборува за борба меѓу Тервингите и Тајфалите од една и Гепидите и Вандалите од друга страна, ${ }^{50}$ но како што ќе видиме понатаму, ова сведоштво е проблематично. Волфрам смета дека Касиодор го сместил овој настан кај Галтис и го вметнал Острогота таму. Самиот Волфрам вели дека колку и да изгледа апсурдна приказната во Гетика, сепак таа е потврдена од новите фрагменти на Дексип - но, на еден поинаков начин. ${ }^{51}$ Неговиот главен став, по појавата на новите фрагменти, е дека навистина постоела историска личност со име Острогота, но тој ниту бил крал, ниту имал кралско потекло, и не бил никаков предок ниту на династијата Амали ниту на Остроготите (кои во тоа време најверојатно се уште не постоеле како такви); тој бил обичен готски војсководач чие име значи ,сјаен Гот“. ${ }^{52}$ Волфрам предлага дека за да се реши проблемот „Касиодор-Острогота“, потребно е Острогота да се подели на две или на три личности: еден би бил

${ }^{46}$ Wolfram, 2018: 447-457. Пред објавувањето на оваа статија, веќе кон средината на својата деветта животна деценија, Х. Волфрам одржа и неколку предавања на европски универзитети (во 2016 и 2017 г.), меѓу кои и воведното предавање (Ostrogotha - ansischer Amaler oder glückloser Feigling?) на големата конференција посветена на новите фрагменти од Дексип, „Empire in Crisis - Gothic Invasions and Roman Historiography“, што се одржа од 3 до 6 мај 2017 година во организација на Универзитетот во Виена и Австриската академија на науките.

${ }^{47}$ Cassiod., Variae, 9.25.5.

${ }^{48}$ Wolfram, 2018: 447.

49 Ibid., 448:,,Der Ostrogotha der Getica steht genau an dieser Schnittstelle zwischen mythicher Origo und Historie“.

${ }^{50}$ XII Panegyrici: XI (III) 17, 1.

${ }^{51}$ Wolfram, 2018: 451.

${ }^{52}$ Ibid., 451. 
митскиот предок на Амалите и Остроготите како фиктивен лик, втор би бил обичниот водач Острогота кој живеел кон средината на III век; и евентуално еден трет обичен водач Острогота би живеел кон крајот на III век. ${ }^{53}$ Последниве двајца не би биле предци на Остроготите, туку едноставно личности кои го носат името „сјаен Гот“. И повторно, во крајната реконструкција Волфрам потврдува дека е можно во III век да живееле двајца војсководачи по име Острогота, и дека ракописот од Виена всушност сведочи за постариот од нив кој живеел во средината на векот. ${ }^{54}$

Новата хипотетичка реконструкција на Х. Волфрам во голема мера се должи на рационална и сеопфатна анализа на изворите. Меѓутоа се чини дека во еден дел таа се должи на непотребна анализа, а во друг дел е растегната до максимум. Имено, долгите докажувања дека "праисторијата“" на Готите во почетниот дел на Гетика е во најголема мера митологизирана не решава ништо во конкретното прашање за реалноста или фиктивноста на Острогота. Одамна е општо познато и досега неоспорено дека Јорданес вештачки ги вметнува Готите во приказните за најстарите цивилизации. ${ }^{55}$ Дискусиите за тоа како функционира митот сигурно беа корисни и релевантни во време кога Острогота беше познат од само еден извор, но во оваа ситуација тие веќе не се пресудни. Навистина, расказот за потеклото на Амалите во наратолошката структура на Гетика доаѓ веднаш по еден фабрикуван дел каде Јорданес ги става Готите на местото на Даките, но од друга страна останатите епизоди во кои се споменува Острогота веќе се дел од веродостојни пошироки историски процеси што ни се познати од други извори. Според тоа, дали мораме да го сместиме Острогота во митологизираниот дел на делото? Од наративен аспект, Острогота може подеднакво да се разгледува и како историска фигура. Понатаму, во својот третман на нарацијата од Гетика, Х. Волфрам се насочува само кон Касиодор како нејзин извор, а сосема го занемарува Јорданес. Тука е можеби една од главните слабости во анализата, зашто ваквиот пристап го ограничува на разгледување на приликите само во Италија во време на Теодорих. Политичките прилики во Константинопол во средината на VI век, или пак некои други социо-културни фактори, воопшто не се присутни во анализата. Ваквото ограничување може да ја одведе целата дискусија во погрешен правец, бидејќи старата дилема "Касиодор или Јорданес“" во авторството на Гетика не е докрај решена, но сигурно е дека улогата на вториов, макар и само препишувач, не смее да се занемари. И можеби најважно во конкретниов случај, Јорданес бил запознаен со делата на Дексип, на кого се повикува во

${ }^{53}$ Ibid., 452.

${ }^{54}$ Ibid., 453.

55 За оваа проблематика веќе пишувавме поопширно во Пановски \& Стојанов, 2016: 47-70. 
својата историја, ${ }^{56}$ па според тоа Острогота кој досега единствено се споменуваше кај него, можеби доаѓ директно од Дексип а не од Касиодор. Дилемата за авторството може да се покаже релевантна и во анализата на генеалогијата на Амалите, за која не знаеме дали е целосно препишана од страна на Јорданес. Освен тоа, инсистирањето на бројката 17 , односно седумнаесетте генерации, како доказ за манипулација според древен римски модел веќе била силно оспорувана во минатото. ${ }^{57}$ Имено, постоеле повеќе различни традиции за улогата и односот меѓу Ајнеја од една и Ромул и Рем од друга страна; ${ }^{58}$ згора на тоа, Острогота не е во првите тричетири имиња на списокот кои очигледно се митолошки, туку е на шестото место. Аргументот пак дека животот на Острогота би требало да се помести кон крајот на III век затоа што извесен панегирик спомнува војна на Тервингите и Тајфалите со Гепидите и Вандалите не е воопшто уверлив, и поскоро служи за да одговара на одредена посакувана реконструкција. Имено, конфликтите меѓу разните барбарски групи како во III век така и во текот на целиот доцноантички период не се ниту ретки ниту невообичаени, и затоа, и покрај тоа што Јорданес не е секогаш најпрецизен со хронологијата, нема потреба денес да се "поместува“" еден настан за 40 години за да му се обезбеди контекст. Всушност, ако малку повнимателно се прочита извадокот од панегирикот веднаш станува јасно колку е произволно понуденото решение.

„Дивите Маври беснеат врз сопственото месо, Готите сосема ги сотреа Бургундите, Аламаните, а исто и Тервингите, повторно се вооружуваат во полза на поразените; друга група Готи, здружена со Тајфалите, се судира со Вандалите и Гепидите. Хормизда здружен со Саките, Руфите и Гелите удира врз Персијичте и нивниот крал, и не ги почитува ниту кралското величие, ниту братската верност. Бургундите ја зазедоа земјата на Аламаните, но по цена на страшни загуби. Аламаните ја загубија земјата но се трудат повторно да ја освојат. Колку е моќно вашето божество! Не само што овие и други племиња, страшни по

${ }^{56}$ Iord., Getica, 22.113. Податоците што тука ги презема од Дексип се однесуваат на историјата на Вандалите, така што логично е да се претпостави дека потекнуваат од „Скитика“ (и покрај тоа што Дексип напишал уште две други дела: Историја на настаните по Александар и една Хроника). Малку понатаму, пак, описот на битката кај Бероја (Iord. Getica, 18.102) содржи елементи кои имаат извесна сличност со говорот на императорот Декиј пред војската во листот $194^{\mathrm{v}}$ од новите фрагменти на Дексип, што исто оди во прилог на врската Дексип - Јорданес во преносот на информации.

${ }^{57}$ Goffart, 2002: 21-37. За дилемите во случајот на лангобардскиот крал Ротари во 7 век, $c f$. Gillet, 2002: 88, n.10.

58 Така, во една традиција Ромул е син на Ајнеја, во друга пак негов внук. Дури има и традиција каде Рем, а не Ромул е основач на првиот Рим што по некое време бил напуштен, а генерации подоцна бил преоснован од Ромул и Рем. Само во третава традиција се споменува дека Ромул е седумнаесетти потомок на Ајнеја. v. Dion. Halicar., i.73. $c f$. i.45. 
број и оружје, имајки доверба во вас се подготвени за уништување на барбарството, туку слушам и Блемите, навикнати само на лесни стрели, бараат оружје што го немаат за борба против Ајтиопјаните, и небаре од чиста омраза се впуштаат во убиствен $60{ }^{\prime \prime} .59$

Како што може да се забележи ниту Острогота, ниту Фастида не се споменуваат во панегирикот. Веќе ова е доволно за да се сомневаме во оправданоста настанот опишан кај Јорданес да се поместува четири децении подоцна. Згора на тоа, ние не сме сосема сигурни кој дел од Готите се судрил со Вандалите и Гепидите во оваа прилика. Имено дел од издавачите претпочитаат по Тервингите да се стави точка-запирка, а некои пак (вклучително и Х. Волфрам) запирка. ${ }^{60}$ Како што може да се забележи ние го претпочитаме првото решение што делува посоодветно. ${ }^{61}$ Иако не е невозможно да стои запирка, таквото решение непотребно ја компликува и онака долгата реченица. Згора на тоа, ако авторот сакал да го издвои дејствувањето на Алеманите од она на Тервингите, тогаш изборот на itemque делува крајно невешто, па дури и спротивно на првиот дел од реченицата каде дејствијата на различните племиња едноставно се одвоени со запирка без дополнителни прилози и објаснувања.

Всушност, главниот аргумент за менување на интерпункцискиот знак е тоа што ако се задржи точка-запирка ние би биле соочени со трета и неидентификувана група на Готи. Аргументот е валиден само ако цврсто се држиме до догматската поделба на Готите на Тервинги и Греутунги и не оставаме место за други помали групации. Напротив, од изворите знаеме дека Готите дејствувале во повеќе различни групи и подгрупи, не сите обединети околу Греутунгите и Тервингите. Секако еден од најдобро познатите примери е групацијата на Радагаис, кој во еден момент се чини успеал да собере повеќе од 10.000 борци. Иако неговата група била составена од борци од различни племиња, јадрото го сочинувале Готите. ${ }^{62}$ Според тоа, споменувањето на трета група ниту треба да нѐ збунува ниту пак да нѐ принудува да инсистираме на идентификување со Тервингите. Така, не само што Острогота воошто и не е споменат во панегирикот, туку ние не можеме со сигурност да кажеме ниту кои Готи се судриле со Гепидите и Вандалите во оваа прилика.

\footnotetext{
${ }^{59}$ Panegyrici Latini XI.17.
}

${ }^{60}$ Дискусија со основна литература кај Nixon \& Rodgers, 1994: 100-101 n.82.

${ }^{61}$ Furit in uiscera sua gens Maurorum, Gothi Burgundos penitus excidunt, rursumque pro uictis armantur Alamanni itemque Teruingi; pars alia Gothorum adiuncta manu Taifalorum aduersum Vandalos Gipedesque concurrunt.

62 v. Heather, 1994: 14-15. 
Што се однесува пак до статусот на Острогота, според Х. Волфрам, Книва би бил rex, а Острогота само $d u x .{ }^{63}$ Но, ако веќе се прифаќа неговото постоење во средината на III век, нема потреба да се негира неговиот кралски статус. Навистина, во доцната антика разликата меѓу rex и $d u x$, односно меѓу reiks, thiudans и drauhtins не треба да се занемарува, но прашање е колку таа е видлива и суштинска во III век. Истовремено, треба да се нагласи дека и Јорданес директно ${ }^{64}$ и Дексип индиректно го третираат Острогота како готски крал. Во дискурсот на Јорданес, Острогота е тој што регрутира сојузници од соседството, назначува готски војсководачи, и е одговорен за судбината на сите Готи. Навистина, во новите фрагменти на Дексип Острогота е arkhon, а Книва basileus, но прашање е во колкава мера тој бил непосредно запознаен со внатрешните хиерархиски односи меѓу Готите. Во таа смисла, индикативна е информацијата на Дексип дека Острогота не можел да го поднесе растот на репутацијата на Книва и „за да се оправда пред сите Скити“ собрал огромна војска и тргнал во акција (Codex Vindobonensis Hist. gr. 73, f.194'). Ова секако не остава впечаток на потчинетост на Острогота во однос на Книва, туку попрво на двајца сопернички водачи.

Конечно, со потврда од два историски извори и по нови историографски дискусии, сметаме дека е сосема оправдано да се прифати дека во средината на III век постоела реална историска личност, готски крал, Острогота. Навистина, историските процеси кои се предмет на анализа не се целосно разјаснети и документирани, но новите фрагменти од „Скитика“ на Дексип овозможуваат да се направи мал исчекор напред во разбирањето на историјата на Готите и нивните односи со царството во III век. Во секој случај, сметаме дека дел од аргументацијата која некогаш го негираше Острогота и го сметаше за фиктивен лик, а денес го поместува во сосема друго време или пак го смета за историска личност без кралска власт, е поставена на погрешни основи.

\section{БИБЛИОГРАФИЈА}

Burns, T. S., "Theories and Facts. The Early Gothic Migrations", History in Africa 9 (1982), 1-20.

Christol, M., L'Empire romain du IIIe siècle. Histoire politique (de 192, mort de Commode, à 325, concile de Nicée), Paris, 1997.

${ }^{63}$ Сосема спротивно е мислењето на Девиље, според кого Острогота би бил крал (доколку навистина постоел), а Книва би бил обичен војсководач, (Devillers, 1995: 150, n.162).

${ }^{64}$ Iord., Getica, 16.90, 17.98 (каде дури нагласува дека Острогота бил владетел и на Остроготите и на Визиготите, т.е. на се уште неподелените Готи), и 17.99. 
Davenport, C. \& Mallan, C., "Dexippus' Letter of Decius: Context and Interpretation", Museum Helveticum 70 (2013), 57-73.

Frantz, A., The Athenian Agora. Results of Excavations Conducted by the American School of Classical Studies at Athens, vol. 24: Late Antiquity: A.D. 267-700, Princeton, 1988.

Geary, P., Quand les nations refont l'histoire: l'invention des origines médiévales de l'Europe, Paris, 2004.

Gillett, A., Was Ethnicity Politicized in the Earliest Medieval Kingdoms?, in: A. Gillet (ed.), On Barbarian Identity, Turnhout, 2002, 85-121.

Goffart, W., "Does the Distant Past Impinge on the Invasion Age Germans?", in: A. Gillett (ed.), On Barbarian Identity. Critical Approaches to Ethnicity in the Early Middle Ages, Turnhout, 2002, 21-37.

Goltz, A., "Das Imperium Romanum in der Defensive. Von den Markomannenkriegen des Marcus Aurelius bis zu den Siegen des Iulianus Apostata”, in: H. Schneider (Hg.), Feindliche Nachbarn. Rom und die Germanen, Köln, 2008, 201-227.

Grusková, J. Untersuchungen zu den griechischen Palimpsesten der Österreichischen Nationalbibliothek. Codices Historici, Codices Philosophici et Philologici, Codices Iuridici, Veröffentlichungen zur Byzanzforschung XX. Denschriften der philosophisch-historischen Klasse der Österreichischen Akademie der Wissenschaften 401, Wien, 2010.

Grusková, J. "Further Steps in Revealing, Editing and Analysing Important Ancient Greek and Byzantine Texts Hidden in Palimpsests", Zbornik Filozofickej Fakulty Univerzity Komenskeho 33-34 (2012), 69-82.

Grusková, J. \& Martin, G., “Ein neues Textstück aus den „Scythica Vindobonensia“ zu den Ereignissen nach der Eroberung von Philippopolis", Tyche 29 (2014), 29-43.

Grusková, J. \& Martin, G., "Zum Angriff der Goten unter Kniva auf eine thrakische Stadt (Scythica Vindobonensia, f. 195v)", Tyche 30 (2015), 35-53.

Grusková, J. \& Martin, G., "Rückkehr zu den Thermopylen. Die Fortsetzung einer Erfolgsgeschichte in den neuen Fragmenten Dexipps von Athen", in: A. Eich, S. Freund, M. Rühl und Ch. Schubert (Hrsg.), Das dritte Jahrhundert. Kontinuitäten, Brüche, Übergänge, Stuttgart, 2017a, 267-281.

Grusková, J. \& Martin, G., "Neugelesener Text im Wiener Dexipp-Palimpsest (Scythica Vindobonensia, f. 195v, Z. 6-10) mit Hilfe der Röntgenfluoreszenzanalyse", ZPE 204 (2017b), 40-46.

Heather, P., "Cassiodorus and the Rise of the Amals. Genealogy and the Goths under Hun Domination", JRS 79 (1989), 103-128.

Heather, P., Goths and Romans, Oxford, 1994.

Hostein, A., "Note sur les dariques de Cniva (Dexippus Vindobonensis) et autres curiosités "barbares", Revue Numismatique (2017), 37-64.

Jordanès, Histoire des Goths, introduction, traduction et notes par Olivier Devillers, Paris, 1995.

Kulikowski, M., Rome's Gothic Wars, Cambridge, 2006.

Mallan, C. \& Davenport C., "Dexippus and the Gothic Invasions: Interpreting the New Vienna Fragment (Codex Vindobonensis Hist. gr. 73, ff. 192v-193r)", JRS 105 (2015), 203-226.

Martin, G. \& Grusková, J., “'Dexippus Vindobonensis'? Ein neues Handschriftenfragment zum sog. Herulereinfall der Jahre 267/8”, Wiener Studien 127 (2014a), 101-120.

Martin, G. \& Grusková, J., “'Scythica Vindobonensia' by Dexippus(?): new fragments on Decius' Gothic wars", GRBS 54/4 (2014b), 728-754.

Millar, F., "P. Herennius Dexippus: The Greek World and the Third-Century Invasions", JRS 59.1-2 (1969), 12-29.

Mussot-Goulard, R., Les Goths, Biarritz, 1999.

Nixon, C. E. V. \& Rodgers, B. S., In Praise of Later Roman Emprerors. The Panegyrici Latini, Berkeley-Los Angeles-London, 1994. 
Пановски, С. \& Стојанов, Д., “Кога митот и историјата се среќаваат: Getica 10.6566”, ГИНИ 60.1 (2016), 47-70.

Piso, I. "Bemerkungen zu Dexippos Vindobonenesis (I)", Göttinger Forum für Altertumswissenschaft 18 (2015), 199-215.

Schukin, M. B., Kazanski, M. \& Sharov, O., Des les Goths aux Huns. Le nord de la Mer Noire au Bas-Empire et a l'epoque des grandes migrations, Oxford, 2006.

Wolfram, H., Histoire des Goths, Paris, 1990.

Wolfram, H., "Gothic History as Historical Ethnography", in: Th. F.X. Noble (ed.), From Roman Provinces to Medieval Kingdoms, London \& New York, 2006, 43-69.

Wolfram, H., "Ostrogotha - ein mythischer Amaler erhält zumindest einen historischen Namensvetter", in: J. Drauschke, E. Kislinger, K. Kühtreiber, T. Kühtreiber, G. Scharrer-Liška, T. Vida (Hrsg.) Lebenswelten zwischen Archäologie und Geschichte Festschrift für Falko Daim zu seinem 65. Geburtstag, Monographien des Römisch-Germanischen Zentralmuseums Band 150, Mainz, 2018, 447-457.

\author{
Darko LEITNER-STOJANOV \\ Stefan PANOVSKI \\ Institute for National History \\ Skopje, Macedonia
}

\title{
THE SAGA OF OSTROGOTHA AND CODEX VINDOBONENSIS HIST. GR. 73 (SUMMARY)
}

The exciting discovery of the new fragments from Dexippos' Scythica opened new avenues for inquiry and reexamination of some older questions pertaining the history of the $3^{\text {rd }}$ century and the barbarian inroads in the Roman provinces. One of those questions is the historicity of the Gothic king Ostrogotha, a question considered closed for a long time. Mentioned only in Jordanes' Getica, positioned amongst mythical rulers, and bearing a name of people who did not yet exist, it was generally acknowledged that he is another mythical character invented much later. This changed with the discovery of the new fragments where Ostrogotha is mentioned on two occasions - envious of Kniva's victories and his high standing among the "Scythians", Ostrogotha gathers a large army and moves against Decius (194 ${ }^{\mathrm{r}}$ ); and afterwards Decius is informed of Ostrogotha's approach $\left(194^{v}\right)$. On the one hand, not only do the new fragments bring to light a historical figure long thought to be a mythical construction, but offer a fresh insight into practices and customs attested among the barbarian tribes (rivalry among various tribe leaders, songs honoring current leaders etc.). On the other, they create new problems especially in relation to Jordanes' account - exactly at the point where we would expect Ostrogotha to die and be succeeded by Kniva, not only is he alive and well but seems to be at odds or at least in a state of rivalry with Kniva. This raises a whole set of questions - how long after 250 did Ostrogotha live; are the Gothic attacks of 250251 a joint enterprise of at least two leaders; why did Jordanes dismiss him 
from the narrative too soon? But first, another and fundamental question needs to be answered.

In light of the new fragments few would disagree that we are dealing with a historical person. But if that is so, then what was his role and his status especially in relation to Kniva, and finally what are we to do with the description in Jordanes? One of the first to offer an answer is the distinguished scholar $\mathrm{H}$. Wolfram whose theories have dominated the field for the past half a century. In his opinion, in order to solve the problem Cassiodorus - Ostrogotha, the latter needs to be separated into two and possibly three different persons - one fictitious and belonging to the mythical past, another in the middle of, and a third towards the end of the $3^{\text {rd }}$ century; additionally, the two historical persons were not kings, but military leaders. Despite his thorough analysis, the conclusion is not convincing. Concerning the fictitious one, by focusing solely on Cassiodorus, and insisting on the political agenda of Theodoric, Wolfram, ignores the potential role Jordanes might have had in the creating of the Ostrogothic genealogy, and therefore ignores the political and intellectual climate in Constantinople in the $6^{\text {th }}$ century. This is all the more important not only because the question of Jordanes' reliance or the lack thereof on Cassiodorus' work is still open for debate, but also because Jordanes seems to be familiar with the work of Dexippos. The idea that Theodoric's position as seventeenth descendant in line shows the artificiality of the list since Romulus was seventeenth in line as well, is problematic for various reasons, not least because there were alternative traditions where Romulus was son or grandson of Aeneas. In the end, no one questions the conclusion that the opening chapters of Jordanes' Getica are un-historical; yet, the other references to Ostrogotha, especially in light of the new fragments, can safely be put in the middle of the $3^{\text {rd }}$ century. Regarding the third one, who might have lived towards the end of the $3^{\text {rd }}$ century, the argument is based on the information in the Panegyrici latini, where a battle is mentioned between the Goths and Taifali on the one side and Gepids and Vandals on the other (XI.17). However, neither Ostrogotha nor Fastida are mentioned in the text. Additionally, we are not certain what group of Goths took part in the battle since the question whether there should be a semicolon or a comma after Teruingi is still open. Therefore, even though the chronology in Jordanes presents problems of its own, there is no good reason to transpose an event some four decades later.

Concerning the status of Ostrogotha in relation to Kniva, though a definitive answer seems impossible at this time, the general impression is that he was a king after all. In Jordanes it is he who recruits allies, appoints commanders, and is responsible for the wellbeing of the people, while Kniva is his successor. On the other hand, Dexippos does call Kniva basileus, while Ostrogotha is an arkhon; yet his reaction to Kniva's successes does not give the impression of one who is a subordinate, rather an equal and a rival.

The debate is far from over, on the contrary it is just beginning, and therefore a definitive answer to the questions raised in the paper is impossible at this time. Still, all things considered, we would tentatively ascribe to the theory that we should be operating with only one Ostrogotha, who was probably a king and lived in the mid $3^{\text {rd }}$ century. 